\title{
De novo AVM formation following venous sinus thrombosis and prior AVM resection in adults: report of 2 cases
}

\author{
Siyu Shi, Raghav Gupta, Justin M. Moore, MD, PhD, Christoph J. Griessenauer, MD, \\ Nimer Adeeb, MD, Rouzbeh Motiei-Langroudi, MD, Ajith J. Thomas, MD, and \\ Christopher S. Ogilvy, MD
}

\begin{abstract}
Department of Surgery, Division of Neurosurgery, Beth Israel Deaconess Medical Center, Harvard Medical School, Boston,
\end{abstract} Massachusetts

\begin{abstract}
Brain arteriovenous malformations (AVMs) are traditionally considered congenital lesions, arising from aberrant vascular development during the intrauterine period. Rarely, however, AVMs develop in the postnatal period. Individual case reports of de novo AVM formation in both pediatric and adult patients have challenged the traditional dogma of a congenital origin. Instead, for these cases, a dynamic picture is emerging of AVM growth and development, initially triggered by ischemic and/or traumatic events, coupled with genetic predispositions. A number of pathophysiological descriptions involving aberrant angiogenic responses following trauma, hemorrhage, or inflammation have been proposed, although the exact etiology of these lesions remains to be elucidated. Here, the authors present 2 cases of de novo AVM formation in adult patients. The first case involves the development of an AVM following a venous sinus thrombosis and to the authors' knowledge is the first of its kind to be reported in the literature. They also present a case in which an elderly patient with a previously ruptured AVM developed a second AVM in the contralateral hemisphere 11 years later. In addition to presenting these cases, the authors propose a possible mechanism for de novo AVM development in adult patients following ischemic injury.
\end{abstract}

https://thejns.org/doi/abs/10.3171/2016.9.JNS161710

KEY WORDS de novo AVM; venous sinus thrombosis; adult; angiogenesis; vascular disorders

B RAIN arteriovenous malformations (AVMs) are direct, abnormal connections between arteries and veins without intervening capillary beds..$^{15}$ Parenchymal AVMs have traditionally been considered congenital lesions, arising from aberrant vascular development during the intrauterine period ${ }^{20}$ However, individual case reports published over the past 2 decades have suggested that other mechanisms may also play a role in de novo AVM development and that these lesions are both dynamic and reactive..$^{2,4-8,11-14,17-19,22,23,25-27}$ De novo AVM formation has been documented following diagnosis of other conditions, including moyamoya disease, Bell's palsy, cavernous malformations, dural arteriovenous fistulas, intracranial hemorrhage, seizures, hydrocephalus, and transient ischemic attacks. While cases of this kind have been well characterized in pediatric patients, $4,8,12,18,22,25-27$ reports of de novo AVM formation in adult patients are rare. Here, we present 2 cases of de novo AVM formation in adults following diagnosis of venous sinus thrombosis and a previous contralateral AVM.

ABBREVIATIONS AVM = arteriovenous malformation; $C T A=C T$ angiography; DAVF = dural arteriovenous fistula; $D S A=$ digital subtraction angiography; $M R V=$ MR venography. 

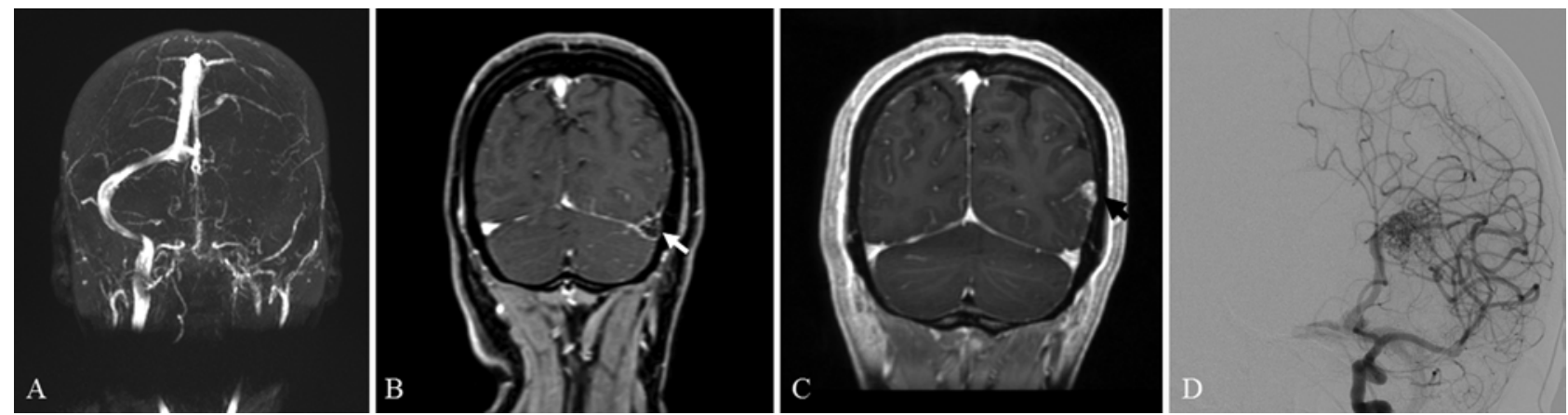

FIG. 1. Case 1. A: Magnetic resonance venography image indicates the presence of a left transverse sinus thrombosis. B: Coronal MR image confirms a venous thrombosis (white arrow) without evidence of a left temporooccipital AVM. C: Coronal MR image obtained 2 years later demonstrates resolution of the thrombosis and indicates the presence of a de novo AVM on the ipsilateral hemisphere. D: Image obtained with DSA confirms an AVM fed by the left distal middle cerebral artery.

\section{Case Reports}

Case 1

A 31-year-old woman initially presented with a severe headache. Magnetic resonance venography (MRV) demonstrated a left transverse sinus thrombosis with no evidence of hemorrhage, associated infarct, or other vascular abnormality (Figs. 1 and 2). A 6-month course of anticoagulant therapy was initiated, and the sinus was recanalized. Routine MRI performed at the 2-year followup indicated a new $1.26 \times 0.75-\mathrm{cm}$ left temporooccipital AVM. Digital subtraction angiography (DSA) confirmed the presence of the lesion. After a detailed consultation, a conservative management strategy was undertaken and the patient was subsequently discharged to home.

\section{Case 2}

A 61-year-old man initially presented acutely with gait instability. Computed tomography angiography (CTA) and DSA confirmed a hemorrhagic left frontal AVM at the time, with no other vascular abnormalities. The patient had no history or family history of hereditary hemorrhagic telangiectasia. Microsurgical resection of the AVM was performed uneventfully, although postoperative care
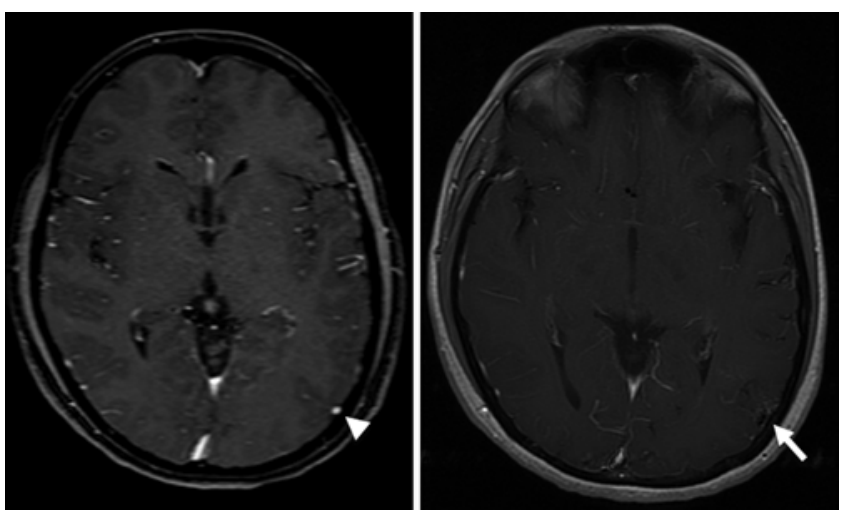

FIG. 2. Case 1. Left: Contrast-enhanced MR image shows a draining vein in the left temporooccipital region (arrowhead). Right: Contrastenhanced MR image obtained 2 years later confirms an AVM emanating from the region where the draining vein had been previously visualized (arrow). was complicated by seizures, which were successfully controlled by anticonvulsant medications. Follow-up CTA confirmed complete obliteration of the lesion (Fig. 3). Eleven years after the resection, the patient presented with left hemianopsia. Computed tomography angiography and DSA confirmed a right temporooccipital hemorrhage and associated de novo AVM. The patient underwent microsurgical resection of this second lesion. Follow-up imaging confirmed complete obliteration of the lesion, and the patient was subsequently discharged to home neurologically intact.

\section{Discussion}

AVM formation is believed to result from aberrant vasculogenesis and angiogenesis occurring in utero. However, limited data exist to support the congenital nature of these lesions, with only $1 \%$ being diagnosed before the age of 2 years. ${ }^{19}$ Koch et al. recently summarized 19 cases of de novo AVMs reported in the literature over the past 2 decades. ${ }^{14}$ As these lesions typically develop following either a traumatic brain injury or an ischemic event, these case descriptions have lent support to a dynamic and reactive theory of AVM development. While the underlying pathophysiology remains unclear, loss-of-function mutations in the activin receptor-like kinase $1(A L K I)$ and/or the endoglin $(E N G)$ genes have been proposed as the basis for aberrant angiogenesis and subsequent development of these lesions. ${ }^{19,21}$ The effects of these mutations occur via the vascular endothelial growth factor (VEGF) and transforming growth factor (TGF- $\beta$ ) pathways., ${ }^{9} 10$

To date, only 11 de novo AVMs have been diagnosed in adult patients, with no previous reports of cases that developed following venous sinus thrombosis (Table 1). $2,5,6,11-14,17,19,23$ While venous sinus thrombosis has been implicated in dural arteriovenous fistula (DAVF) formation, its role in the development of parenchymal AVMs is poorly understood. In 1997 Lawton et al. demonstrated in a rat model that increased venous pressure resulting from sinus thrombosis led to an increase in angiogenesis and facial AVM formation..$^{16}$ Aboian et al. have suggested that venous outflow occlusion and the resulting venous hypertension may induce hypoxia in neighboring parenchyma, consequently leading to increased angiogenic activity and 

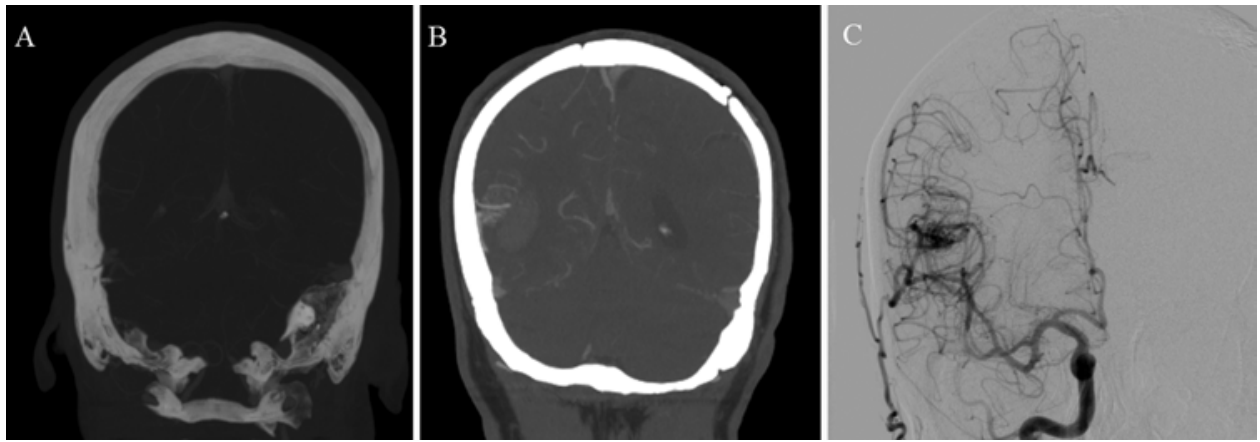

FIG. 3. Case 2. A: Computed tomography angiogram indicates an AVM in the left frontal region. No evidence of vascular abnormalities in the contralateral hemisphere was observed. B: Another CTA image acquired 11 years later indicates a de novo AVM in the right temporooccipital region. C: A DSA image confirms the AVM is fed by the distal right middle cerebral artery.

lesion formation. ${ }^{1}$ In the presence of the aforementioned genetic abnormalities, these conditions may result in uncontrolled vascularization of the tissue. Morales-Valero et al. proposed that once a nidus develops and supports rapid blood flow, shear stress on the endothelial lining of the newly formed, fragile vessels can serve as the stimulus for further angiogenic activity. ${ }^{19}$ We theorize that a draining vein in Case 1, which was visible on MRI at the time of

TABLE 1. Literature review of adult de novo intracranial AVMs

\begin{tabular}{|c|c|c|c|c|c|c|c|c|}
\hline \multirow[b]{2}{*}{$\begin{array}{l}\text { Authors \& } \\
\text { Year }\end{array}$} & \multicolumn{4}{|c|}{ Initial Presentation } & \multicolumn{4}{|c|}{ De Novo AVM Formation } \\
\hline & $\begin{array}{l}\text { Age at } \\
\text { Baseline } \\
\text { Imaging } \\
\text { (yrs), Sex }\end{array}$ & Symptoms & $\begin{array}{l}\text { Imaging } \\
\text { Modality }\end{array}$ & $\begin{array}{l}\text { Underlying } \\
\text { Pathology }\end{array}$ & $\begin{array}{l}\text { Age } \\
\text { at Dx } \\
\text { (yrs) }\end{array}$ & Symptoms & $\begin{array}{l}\text { Imaging } \\
\text { Modality }\end{array}$ & Location \\
\hline $\begin{array}{l}\text { Friedman et } \\
\text { al., } 2000\end{array}$ & $61, \mathrm{M}$ & $\begin{array}{l}\text { Vertigo, vomiting, rt arm } \\
\text { dysmetria, nystagmus }\end{array}$ & $\begin{array}{l}\text { CT, MRI, } \\
\text { DSA }\end{array}$ & Rt tentorial DAVF & 68 & Asymptomatic & DSA & Rt cerebellum \\
\hline $\begin{array}{l}\text { Bulsara et } \\
\quad \text { al., } 2002\end{array}$ & $26, \mathrm{~F}$ & $\begin{array}{l}\text { Gait ataxia, nystagmus, dys- } \\
\text { metria, myoclonic jerks }\end{array}$ & $\begin{array}{l}\text { MRI, } \\
\text { DSA }\end{array}$ & $\begin{array}{l}\text { Inflammatory } \\
\text { lesion }\end{array}$ & 32 & $\begin{array}{l}\text { Headache, intraparen- } \\
\text { chymal hemorrhage }\end{array}$ & $\begin{array}{l}\text { CT, MRI, } \\
\text { DSA }\end{array}$ & $\begin{array}{r}\text { Rt posterior } \\
\text { temporal }\end{array}$ \\
\hline $\begin{array}{l}\text { Akimoto et } \\
\text { al., } 2003\end{array}$ & $10, F$ & Intraventricular hemorrhage & CT, DSA & $\begin{array}{l}\text { Lt occipital AVM } \\
\text { \& corpus cal- } \\
\text { losum AVM }\end{array}$ & 27 & $\begin{array}{l}\text { Headache, numbness, } \\
\text { intraparenchymal } \\
\text { hemorrhage }\end{array}$ & $\begin{array}{l}\text { MRI, } \\
\text { DSA }\end{array}$ & $\begin{array}{l}\text { Cingulate gy- } \\
\text { rus, corpus } \\
\text { callosum }\end{array}$ \\
\hline $\begin{array}{l}\text { Jeffree \& } \\
\quad \text { Stoodley, } \\
2009\end{array}$ & $8, M$ & $\begin{array}{l}\text { Headache, facial droop, } \\
\text { speech deficit, vomiting, } \\
\text { decreased consciousness }\end{array}$ & $\begin{array}{l}\text { CT, } \\
\text { DSA, } \\
\text { MRI }\end{array}$ & $\begin{array}{l}\text { Lt parietal hema- } \\
\text { toma }\end{array}$ & 18 & $\begin{array}{l}\text { Headache, face/arm } \\
\text { weakness, vomiting }\end{array}$ & CT, DSA & $\begin{array}{l}\text { Rt parietooc- } \\
\text { cipital }\end{array}$ \\
\hline $\begin{array}{r}\text { Mahajan et } \\
\text { al., } 2010\end{array}$ & $16, F$ & Facial paralysis & MRI & Bell's palsy & 30 & $\begin{array}{l}\text { Migraines, facial } \\
\text { weakness, seizures }\end{array}$ & $\begin{array}{l}\text { CT, MRI, } \\
\text { DSA }\end{array}$ & $\begin{array}{l}\text { Lt frontopari- } \\
\quad \text { etal }\end{array}$ \\
\hline $\begin{array}{r}\text { Ozsarac et } \\
\text { al., } 2012\end{array}$ & $<25,{ }^{*} M$ & Seizures & DSA & Epilepsy & 50 & $\begin{array}{l}\text { Generalized tonic- } \\
\text { clonic seizure }\end{array}$ & CT & $\begin{array}{l}\text { Lt tempopari- } \\
\text { etal }\end{array}$ \\
\hline \multirow{2}{*}{$\begin{array}{l}\text { Morales- } \\
\text { Valero et } \\
\text { al., } 2014\end{array}$} & $31, \mathrm{~F}$ & Obtunded, confused & MRI & $\begin{array}{l}\text { Hepatic encepha- } \\
\text { lopathy }\end{array}$ & 35 & $\begin{array}{l}\text { Intraparenchymal } \\
\text { hemorrhage }\end{array}$ & $\begin{array}{l}\text { MRI, } \\
\text { DSA }\end{array}$ & $\begin{array}{l}\text { Lt parietooc- } \\
\text { cipital }\end{array}$ \\
\hline & $42, \mathrm{M}$ & TIA & DSA & NA & 56 & TIA & DSA & Lt temporal \\
\hline $\begin{array}{l}\text { Neil et al., } \\
2014\end{array}$ & $15, M$ & Seizure & MRI & Epilepsy & 24 & $\begin{array}{l}\text { Generalized tonic- } \\
\text { clonic seizure }\end{array}$ & $\begin{array}{l}\text { MRI, } \\
\text { DSA }\end{array}$ & Lt parietal \\
\hline $\begin{array}{r}\text { Kilbourn et } \\
\text { al., } 2014\end{array}$ & $7, M$ & Absence seizures & CT, MRI & NA & 18 & $\begin{array}{l}\text { Headache, vomiting, } \\
\text { unresponsive }\end{array}$ & $\begin{array}{l}\text { CT, CTA, } \\
\text { DSA }\end{array}$ & Pontine \\
\hline $\begin{array}{l}\text { Koch et al., } \\
2016\end{array}$ & $<2, \dagger F$ & $\begin{array}{l}\text { Ventriculomegaly, balance } \\
\text { loss, inability to sit upright }\end{array}$ & MRI & Ependymoma & 24 & Asymptomatic & $\begin{array}{l}\text { MRI, } \\
\text { DSA }\end{array}$ & Lt choroidal \\
\hline \multirow[t]{2}{*}{$\begin{array}{l}\text { Present } \\
\text { cases }\end{array}$} & $31, \mathrm{~F}$ & Headache & MRV & $\begin{array}{l}\text { Lt transverse si- } \\
\text { nus thrombosis }\end{array}$ & 33 & Asymptomatic & $\begin{array}{l}\text { MRI, } \\
\text { DSA }\end{array}$ & $\begin{array}{l}\text { Lt temporooc- } \\
\text { cipital }\end{array}$ \\
\hline & $61, M$ & Gait instability, hemorrhage & $\begin{array}{l}\text { CTA, } \\
\text { DSA }\end{array}$ & Lt frontal AVM & 72 & $\begin{array}{l}\text { Hemianopsia, hemor- } \\
\text { rhage }\end{array}$ & $\begin{array}{l}\text { CTA, } \\
\text { DSA }\end{array}$ & $\begin{array}{l}\text { Rt temporo- } \\
\text { occipital }\end{array}$ \\
\hline
\end{tabular}

$\mathrm{Dx}=$ diagnosis; $\mathrm{NA}=$ not available; $\mathrm{TI} \mathrm{A}=$ transient ischemic attack.

* Exact age of patient unknown.

$\dagger$ Patient age was 16 months at time of initial presentation. 
the thrombosis and was in the same anatomical location as the de novo AVM (Fig. 2), served as a nidus for arterialization following thrombosis-induced ischemia, resulting in the formation of a high-pressure arteriovenous shunt. Given that the AVM developed within 2 years of the patient's initial MRI, this case illustrates the reactive nature of AVMs.

The average incidence of multiple cerebral AVMs is reported to be $1.9 \% .^{24}$ Only one previous case involving de novo AVM formation following previous AVM resection in a separate location has been reported. ${ }^{2}$ Our second case demonstrates de novo AVM formation in an adult patient following resection of a previously ruptured AVM in the contralateral hemisphere. It is unlikely that the de novo AVM was radiologically occult, as DSA, CTA, and MRI following resection of the first AVM did not show a contralateral AVM. Furthermore, a moderately sized contralateral hematoma would be unlikely to completely occlude an existing AVM. ${ }^{2}$ While recurrence of completely resected AVMs has been reported in the pediatric literature, ${ }^{3}$ reports of de novo AVM formation in adults in different anatomical locations following resection of previous AVMs are extremely rare. This case further substantiates the notion that AVM development is a dynamic process.

\section{Limitations}

In Case 1, only MRV was performed to visualize the venous sinus thrombosis, rather than DSA, which is more sensitive and specific for the detection of AVMs. Therefore we cannot rule out the presence of a radiologically occult, small AVM beyond the resolution of MRI. However, the lesion was easily detected on routine MRI at 2 years, adding weight to the notion of de novo AVM formation. In Case 2, a complete DSA was performed 11 years prior to diagnosis of the patient's first AVM. Unfortunately, because of the amount of time that had elapsed, the imaging was subsequently expunged from the institution's records. However, the neuroradiology report confirms that no abnormalities on the contralateral side were seen at the time that the DSA was performed.

\section{Conclusions}

We report 2 cases of de novo AVM formation in adults, which challenge the traditional belief that all parenchymal AVMs are congenital and provide support for the theory that AVMs may be acquired in some cases. These cases further establish the dynamic nature of AVMs and suggest that de novo AVM formation can occur in adult patients as well as in pediatric patients. We theorize that venous sinus thrombosis-induced hypertension and outflow occlusion may lead to parenchymal ischemia, increased angiogenic activity, and eventual AVM formation. Further studies are required to elucidate the exact pathophysiology involved in this process.

\section{References}

1. Aboian MS, Daniels DJ, Rammos SK, Pozzati E, Lanzino G: The putative role of the venous system in the genesis of vascular malformations. Neurosurg Focus 27(5):E9, 2009
2. Akimoto H, Komatsu K, Kubota Y: Symptomatic de novo arteriovenous malformation appearing 17 years after the resection of two other arteriovenous malformations in childhood: case report. Neurosurgery 52:228-232, 2003

3. Ali MJ, Bendok BR, Rosenblatt S, Rose JE, Getch CC, Batjer $\mathrm{HH}$ : Recurrence of pediatric cerebral arteriovenous malformations after angiographically documented resection. Pediatr Neurosurg 39:32-38, 2003

4. Alvarez H, Perry V, Solle M, Castillo M: De novo cerebral arteriovenous malformation in a child with previous cavernous malformation and developmental venous anomaly. $\mathbf{J}$ Neurosurg Pediatr 9:327-330, 2012

5. Bulsara KR, Alexander MJ, Villavicencio AT, Graffagnino C: De novo cerebral arteriovenous malformation: case report. Neurosurgery 50:1137-1141, 2002

6. Friedman JA, Pollock BE, Nichols DA: Development of a cerebral arteriovenous malformation documented in an adult by serial angiography. J Neurosurg 93:1058-1061, 2000

7. Fujimura M, Kimura N, Ezura M, Niizuma K, Uenohara $H$, Tominaga T: Development of a de novo arteriovenous malformation after bilateral revascularization surgery in a child with moyamoya disease. J Neurosurg Pediatr 13:647-649, 2014

8. Gonzalez LF, Bristol RE, Porter RW, Spetzler RF: De novo presentation of an arteriovenous malformation. Case report and review of the literature. J Neurosurg 102:726-729, 2005

9. Hao Q, Zhu Y, Su H, Shen F, Yang GY, Kim H, et al: VEGF induces more severe cerebrovascular dysplasia in Eng $^{+/-}$than in Alk1+/- mice. Transl Stroke Res 1:197-201, 2010

10. Hashimoto T, Emala CW, Joshi S, Mesa-Tejada R, Quick CM, Feng L, et al: Abnormal pattern of Tie-2 and vascular endothelial growth factor receptor expression in human cerebral arteriovenous malformations. Neurosurgery 47:910 919,2000

11. Neil JA, Li D, Stiefel MF, Hu YC: Symptomatic de novo arteriovenous malformation in an adult: case report and review of the literature. Surg Neurol Int 5:148, 2014

12. Jeffree RL, Stoodley MA: Postnatal development of arteriovenous malformations. Pediatr Neurosurg 45:296-304, 2009

13. Kilbourn KJ, Spiegel G, Killory BD, Kureshi I: Case report of a de novo brainstem arteriovenous malformation in an 18 -year-old male and review of the literature. Neurosurg Rev 37:685-691, 2014

14. Koch MJ, Agarwalla PK, Stapleton CJ, Ogilvy CS, Loeffler JS: De novo development of a cerebral arteriovenous malformation following radiation therapy: Case report and an update to classical arteriovenous malformation nomenclature. J Clin Neurosci 28:162-167, 2016

15. Lasjaunias P, ter Brugge KG, Berenstein A: Surgical Neuroangiography. Vol. 3: Clinical and Interventional Aspects in Children. Berlin: Springer, 2007

16. Lawton MT, Jacobowitz R, Spetzler RF: Redefined role of angiogenesis in the pathogenesis of dural arteriovenous malformations. J Neurosurg 87:267-274, 1997

17. Mahajan A, Manchandia TC, Gould G, Bulsara KR: De novo arteriovenous malformations: case report and review of the literature. Neurosurg Rev 33:115-119, 2010

18. Mathon B, Blauwblomme T, Bolle S, Dufour C, Nagarra O, Brunelle F, et al: De novo arteriovenous malformation after brain radiotherapy for medulloblastoma in a child. Neurology 81:398-399, 2013

19. Morales-Valero SF, Bortolotti C, Sturiale C, Lanzino G: Are parenchymal AVMs congenital lesions? Neurosurg Focus 37(3):E2, 2014 [Erratum in Neurosurg Focus 39(1):E14, 2015]

20. Mullan S, Mojtahedi S, Johnson DL, Macdonald RL: Embryological basis of some aspects of cerebral vascular fistulas and malformations. J Neurosurg 85:1-8, 1996 
21. Oh SP, Seki T, Goss KA, Imamura T, Yi Y, Donahoe PK, et al: Activin receptor-like kinase 1 modulates transforming growth factor- $\beta 1$ signaling in the regulation of angiogenesis. Proc Natl Acad Sci U S A 97:2626-2631, 2000

22. O'Shaughnessy BA, DiPatri AJ Jr, Parkinson RJ, Batjer HH: Development of a de novo cerebral arteriovenous malformation in a child with sickle cell disease and moyamoya arteriopathy. Case report. J Neurosurg 102 (2 Suppl):238-243, 2005

23. Ozsarac M, Aksay E, Kiyan S, Unek O, Gulec FF: De novo cerebral arteriovenous malformation: Pink Floyd's song "Brick in the Wall" as a warning sign. J Emerg Med 43:e17-e20, 2012

24. Salcman M, Scholtz H, Numaguchi Y: Multiple intracerebral arteriovenous malformations: report of three cases and review of the literature. Surg Neurol 38:121-128, 1992

25. Schmit BP, Burrows PE, Kuban K, Goumnerova L, Scott RM: Acquired cerebral arteriovenous malformation in a child with moyamoya disease. Case report. J Neurosurg 84:677-680, 1996

26. Stevens J, Leach JL, Abruzzo T, Jones BV: De novo cerebral arteriovenous malformation: case report and literature review. AJNR Am J Neuroradiol 30:111-112, 2009

27. Yeo JJY, Low SYY, Seow WT, Low DCY: Pediatric de novo cerebral AVM: report of two cases and review of literature. Childs Nerv Syst 31:609-614, 2015

\section{Disclosures}

The authors report no conflict of interest concerning the materials or methods used in this study or the findings specified in this paper.

\section{Author Contributions}

Conception and design: Ogilvy, Moore, Griessenauer. Acquisition of data: Shi, Gupta, Motiei-Langroudi. Analysis and interpretation of data: Shi, Gupta, Adeeb. Drafting the article: Shi, Gupta. Critically revising the article: Shi, Moore, Griessenauer, MotieiLangroudi. Reviewed submitted version of manuscript: Ogilvy, Moore, Adeeb, Motiei-Langroudi, Thomas. Administrative/ technical/material support: Ogilvy, Griessenauer, Thomas. Study supervision: Ogilvy, Thomas.

\section{Correspondence}

Christopher S. Ogilvy, Department of Surgery, Division of Neurosurgery, Beth Israel Deaconess Medical Center, Harvard Medical School, 110 Francis St., Boston, MA 02215-5501. email: cogilvy@ bidmc.harvard.edu. 